\title{
Spatial structures of heavy metals and nitrogen accumulation in moss specimens sampled between 1990 and 2015 throughout Germany
}

\author{
Winfried Schröder and Stefan Nickel
}

\begin{abstract}
Background: The collection of atmospheric deposition by technical samplers and validated deposition modelling using chemical transport models is spatially complemented by using mosses as bioindicator: since 1990, the European moss survey has been providing data on element concentrations in moss every 5 years at up to 7300 sampling sites. In the moss specimens, heavy metals (since 1990), nitrogen (since 2005) and persistent organic pollutants (since 2010) were determined. Germany participated in all surveys with the exception of that in 2010. In this study, the spatial structures of element concentrations in moss collected in Germany between 1990 and 2015 were comparatively investigated by using Moran's I statistics and Variogram analysis and mapped by use of Kriging interpolation. This is the precondition to spatially join the moss survey data with data collected at other locations within different environmental networks and to validate spatial patterns of atmospheric deposition as derived by technical sampling and modelling.
\end{abstract}

Results: The calculated maps reveal a clear and statistically significant decrease of most heavy metals, but not of nitrogen, in moss. Due to decreasing element concentrations and the unchanged application of the element concentration classification for the mapping, the heavy metal maps for the survey 2015 do no longer depict much spatial variation.

Conclusions: Therefore, in an upcoming study, this analysis needs to be complemented for the heavy metals by calculating maps that depict the spatial structure of survey-specific percentile statistics 1990, 1995, 2000, 2005 and 2015.

Keywords: Atmospheric deposition, European moss survey, Geostatistics, Kriging interpolation, Mapping, Variogram analysis

\section{Background}

Atmospheric deposition of heavy metals, nitrogen and persistent organic pollutants may impact the integrity of ecosystems so that standards aiming at their protection are failed. For instance, atmospheric deposition is correlated with accumulation of pollutants in soils and sediments as well as in vegetation and, consequently, in food webs $[2,4,5,9,20,21]$, Nickel et al. [32, 35, 37, 55, 61,
63]. In Germany, there are eight sites with wet only deposition samplers which are part of the European Monitoring and Evaluation Programme. EMEP is a scientifically based and policy driven programme under the $\mathrm{UNECE}^{1}$ Convention on Long-range Transboundary Air Pollution (CLRTAP) for international co-operation to solve transboundary air pollution problems [72]. In the focus

*Correspondence: stefan.nickel@uni-vechta.de

Chair of Landscape Ecology, University of Vechta, P.O.B. 1553,

49364 Vechta, Germany

${ }^{1}$ United Nations Economic Commission for Europe.

Springer Open

(c) The Author(s) 2019. This article is distributed under the terms of the Creative Commons Attribution 4.0 International License (http://creativecommons.org/licenses/by/4.0/), which permits unrestricted use, distribution, and reproduction in any medium, provided you give appropriate credit to the original author(s) and the source, provide a link to the Creative Commons license, and indicate if changes were made. 


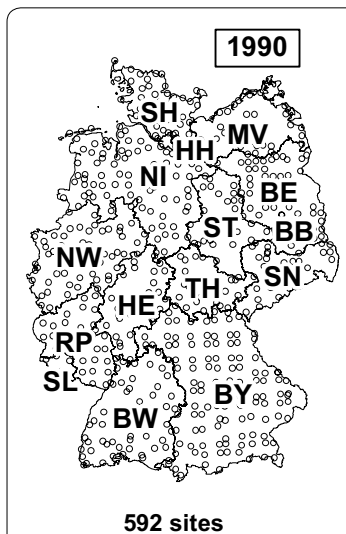

592 sites

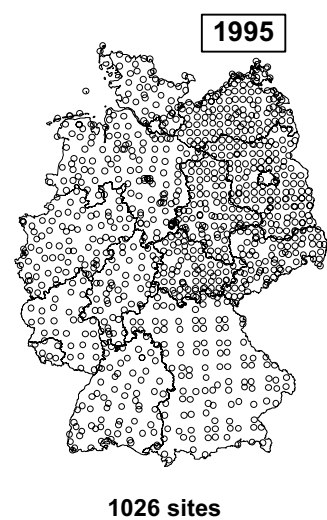

1026 sites

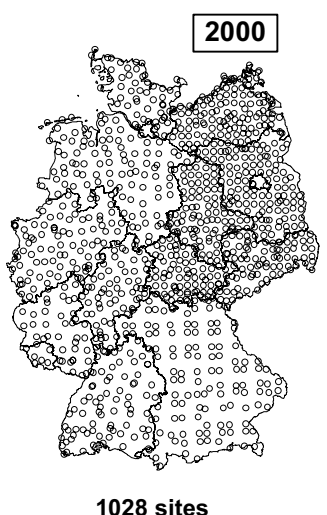

1028 sites

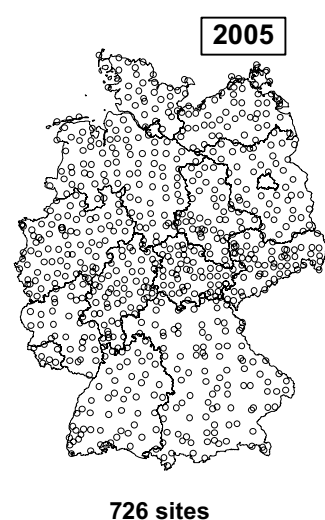

726 sites

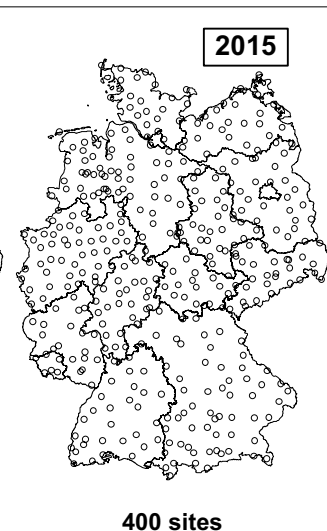

400 sites

Chemical analysis of ...

$\begin{array}{cc}\text { As, Cd, Cr, Cu, Fe, } & \text { Ag, Al, As, B, Ba, Be, Bi, Ca, } \\ \text { Ni, Pb Ti, V, Zn } & \text { Cd, Ce, Co, Cr, Cs, Cu, Fe, } \\ \text { Ga, Ge, Hg, In, K, La, Li, Mg, } \\ \text { Mn, Mo, Na, Nb, Ni, Pb, Rb, } \\ \text { Sb, Sc, Se, Sn, Sr, Ta, Te, Th, } \\ \text { Ti, TI, U, V, W, Y, Zn, Zr }\end{array}$

$\mathrm{Al}, \mathrm{As}, \mathrm{Ba}, \mathrm{Ca}, \mathrm{Cd}, \mathrm{Cr}, \mathrm{Cu}$, $\mathrm{Fe}, \mathrm{Hg}, \mathrm{K}, \mathrm{Mg}, \mathrm{Mn}, \mathrm{Na}, \mathrm{Ni}$, $\mathrm{Pb}, \mathrm{Sb}, \mathrm{Sr}, \mathrm{Ti}, \mathrm{V}, \mathrm{Zn}$

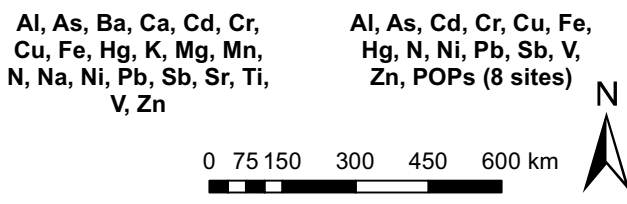

$\mathrm{Cu}, \mathrm{Fe}$

$\mathrm{N}, \mathrm{Na}, \mathrm{Ni}, \mathrm{Pb}, \mathrm{Sb}, \mathrm{Sr}, \mathrm{Ti}$ $\mathrm{V}, \mathrm{Zn}$

\section{$\mathrm{N}$}

Fig. 1 Sampling sites and elements regarded the German Moss Surveys (GMS) 1990, 1995, 2000, 2005, 2015. SH Schleswig-Holstein, MV Mecklenburg-Western Pomerania, HH Hamburg, NI Lower Saxony, BE Berlin; ST Saxony-Anhalt, BB Brandenburg, NW North Rhine-Westphalia, SN Saxony, THThuringia, HE Hesse, RP Rhineland Palatinate, SL Saarland, BY Bavaria, BW Baden-Wuerttemberg

of EMEP, deposition monitoring and modelling are cadmium $(\mathrm{Cd})$, mercury $(\mathrm{Hg})$, lead $(\mathrm{Pb})$ and nitrogen $(\mathrm{N})$. In Europe, the EMEP-deposition network comprises 22 sites where $\mathrm{Hg}$ is measured and 66 with $\mathrm{Cd}$ and $\mathrm{Pb}$ measurements according to a standardised method $[1,6,67]$, Travnikov et al. [68]. The respective data are used to validate results derived by EMEP chemical transport models applied to data on emissions and meteorology. Unfortunately, emission data contain some uncertainty [7, 32-36], so that ecological risks due to deposition cannot be spatially detailed as needed. Therefore, the concentrations of heavy metals (HM) and nitrogen in atmospheric deposition can be evaluated by complementarily method of moss biomonitoring by using ectohydric mosses which lack any roots, cuticle and epidermis [11, 39]. Therefore, they accumulate dry, wet and occult deposition and enable the quantification of elements far beyond the respective limits of analytical detection [8]. Among others, this is especially true for Pleurozium schreberi (BRID.) MITT. (abbreviated as Plesch), Hypnum cupressiforme HEDW. (abbreviated as Hypcup) and Pseudoscleropodium purum (HEDW.) M.FLEISCH (Synonym Scleropodium purum HEDW. LIMPR.) (abbreviated as Psepur) [16]. These species are appropriate for mapping trends of HM bioaccumulation of atmospheric deposition throughout areas of large spatial extent based on a spatially dense network.

Since 1990, European moss surveys (EMS) were conducted every 5 years. Together with the German moss surveys (GMS), being part of EMS with the exception of 2010, they aim at mapping transboundary air pollution by using moss specimens as bioaccumulation indicators. Sampling, chemical analysis and research data management follow a harmonised experimental protocol [16].

The number of sampling sites in six EMS between 1990 and 2015 ranged between 4499 and 7312 in 20 to 36 participating European countries. The number of sampling sites in five GMS (Fig. 1) was reduced from 1026 (1995) and 1028 (2000), respectively, to 726 (2005) and, further on, to 400 (2015) according to a transparent and statistically sound methodology $[34,45,46,59]$. In addition to $\mathrm{Cd}, \mathrm{Hg}, \mathrm{Pb}$ and $\mathrm{N}$, aluminium (Al), arsenic (As), chromium $(\mathrm{Cr})$, copper $(\mathrm{Cu})$, nickel $(\mathrm{Ni})$, vanadium $(\mathrm{V})$ and zinc $(\mathrm{Zn})$ were determined in the moss specimens collected in 2015. This article focus on the LRTAP elements $\mathrm{Cd}, \mathrm{Hg}, \mathrm{Pb}$ and $\mathrm{N}$. Additionally, $\mathrm{Cr}$ is regarded, since this is one of the elements besides antimony $(\mathrm{Sb})$ and $\mathrm{Zn}$ with an intermediate increase in concentration between 2000 and 2005.

This study aims at synoptically compare the spatial structures of element concentrations accumulated in moss in terms of surface maps as derived from sample point data by analysis and modelling of the spatial autocorrelation by means of Variogram analysis and, based on the resulting function, mapping by Kriging interpolation $[24,25]$. Generalising spatial and temporal sample data is an essential goal of empirical sciences. In 
particular, spatial generalisation through interpolation is a precondition for connecting and evaluating measurements derived from monitoring networks being incongruent with the moss monitoring network [32-36]. The explanation of the course of investigation starts with the sampling procedure followed by the chemical analysis of element concentrations including quality control (QC; "Determination of element concentrations in moss" section). QC is an essential precondition for interpreting measurement differences at several points in space and time as real phenomena but not as artefacts. Then, descriptive statistics ("Descriptive statistics" section) and spatial statistics in terms of Moran's I, Variogram analysis and Kriging interpolation ("Geostatistics" section) are outlined.

\section{Methods}

\section{Determination of element concentrations in moss}

The European moss surveys follow a harmonised methodology encompassing the design of the monitoring network, sampling and chemical analyses including QC and data handling. For EMS 2015, this was published by ICP Vegetation [16]. The fundamentals rely on Rühling et al. [48]. They were up-dated continuously [13] and, respectively, specified as, e.g., for Germany [62].

Regarding the reorganisation of the German sampling network, Nickel and Schröder [34] operationalised the given criteria of ICP Vegetation [16]. Examples include: The monitoring network should comprise 1.5 sampling sites within $1000 \mathrm{~km}^{2}$ or at least two sites per EMEPdeposition modelling grid $(50 \mathrm{~km} \times 50 \mathrm{~km})$, regions with steep deposition gradients should be sampled at a higher sample point density, moss sampling points should be located close to sites where atmospheric deposition is collected by technical devices, for enabling time trend analyses, the sampling points should remain the same across time, the sampling should be restricted to the three moss species mentioned in "Background" section.

After a thorough common training, the moss specimens were sampled from June 2016 until March 2017 by five experts according to ICP Vegetation [16]. The same is true for the preparation of the moss specimens by another five members of the lab staff which was subjected to continuous QC, too. The mass concentration of total $\mathrm{N}$ was performed according to VDLUFA [69] using an Elementar Vario Max. The dry and homogeneous moss material was digested with nitric acid (65\%) and hydrogen peroxide (35\%) in a microwave Mars 5 . The measurements of $\mathrm{Al}, \mathrm{As}, \mathrm{Cd}, \mathrm{Cr}, \mathrm{Cu}, \mathrm{Fe}, \mathrm{Ni}, \mathrm{Pb}, \mathrm{Sb}, \mathrm{V}$ and $\mathrm{Zn}$ were performed according to ISO [18] using ICP-MS (Agilent 7900 with sample loop). $\mathrm{Hg}$ was determined according to
ISO [17] by cold vapour atomic absorption spectroscopy (AAS, Mercury) after enrichment with tin(II) chloride.

The limits of quantification for the elements were determined, and the respective results are given in "Quality control of measurement" section. The same applies for the lab-internal QC encompassing for each sampling series the measurement of a blind value and of reference materials to check for recovery and performance. The moss reference materials M2 and M3 ([66] for recommended HM values; [12] for recommended HM and $N$ values) were analysed together with three samples from the EMS 2005 (samples 2071, 3050, 3069) each three times. Lab-external QC was accomplished through certification according to [19] and through national and international ring tests.

\section{Descriptive statistics}

For ensuring the comparability of the five GMS, the same descriptive statistical parameters of GMS 2015 were used for all monitoring campaigns [14, 41, 53, 65]. Thus, for each trace element and $N$, mentioned in "Determination of element concentrations in moss" section, minimum, maximum, arithmetic mean, standards deviation, coefficient of variation in [\%], the 20th, 50th, 90th and 98th percentiles were calculated by taking in consideration all sample point data and specifically for moss species and federal states [38]. In addition, the geostatistical surface estimations were also done ("Geostatistics" section) [62].

\section{Geostatistics}

For mapping the spatial patterns of deposition-induced bioaccumulation of $\mathrm{HM}$ and $N$ and for spatially connecting them with data derived by other environmental monitoring networks, geostatistics [25] was used. Variogram analysis is a geostatistical tool for analysing and modelling spatial autocorrelation of continuous metric variables which are regarded as realisations of random functions (see below). Variogram analysis is a precondition for subsequent spatial surface estimation by Kriging interpolation [24]. Contrary to deterministic interpolation methods, such as inverse distance weighting [3], Kriging uses the geostatistical function derived by Variogram analysis for interpolation. The modelled autocorrelation function informs whether or not and how much the (semi)variance of continuous metric variables is correlated with the distance between measurement points. This function can be evaluated by several characteristics such as the nugget effect indicating measurement variations at spatial ranges below the minimal sample point distance or measurement errors. The range informs about the spatial extent of autocorrelation and, thus, 
Kriging interpolation. The semivariance reached at the maximum spatial extent of autocorrelation is called sill. The nugget-to-sill ratio [\%] is a measure for the strength of spatial autocorrelation: The higher the ratio, the lower the autocorrelation. As a rule of thumb, the nugget-to-sill ratio should not exceed $75 \%$. Ratio values nearby $100 \%$ indicate a random distribution of measurements [10, 22, 71].

A complementary statistical means to account for spatial autocorrelation is suggested by Moran [27]. Moran's $I$ allows for testing whether objects are spatially distributed at random (negative $I$-values) or clustered (positive $I$-values) and whether spatial autocorrelation is significant. The range determined by Variogram analysis can be used in Moran's $I$ statistics to specify the spatial extent of autocorrelation [70].

Following the autocorrelation analysis and modelling, the autocorrelation function was used for Kriging interpolation. Depending from assumptions about the random function, several variants of Kriging interpolation can be applied: two of them are ordinary Kriging, supposing the mean of the random function as constant across the area investigated, and Universal Kriging for data including a deterministic trend [22]. Since most data from environmental surveys do not follow a normal distribution [47], the moss survey data distribution was analysed with regard to their skewness (Sk), and data not normally distributed were subjected to log-transformation [64] and Box-Cox-transformation [49, 71]. The quality of Kriging interpolation was quantified by leave-one-out crossvalidation $[15,22]$. Thereby, the mean error (ME) and the mean standardized error (MSE) indicate over- and underestimation. Optimal values of both measures would be 0 . The root mean square standardised error (RMSSE) accounts for the relation between theoretical and experimental variance. Its optimum value is 1 , and RMSSE $<1$ indicates underestimation and RMSSE $>$ overestimation. The median of percentage errors (MPE [\%]) allows for comparing data covering different orders of magnitude. Cases where cross-validation measures show smaller ranges than empiric measurements indicate a good quality of spatial estimation. To account for this, the corrected mean percentage error (MPEc) can be computed by multiplying MPE with the ratio of the empirical and estimated ranges. Additionally, Olea [40] suggests the correlation coefficient $r$ (Pearson) between estimated and empiric measurements which ideally equal 1.

The geostatistical analyses and modelling were computed by ESRI ArcGIS 10.2, Geostatistical Analyst. For ensuring the reproducibility of spatial estimation, the primary data and all statistical measures explained above were documented and archived [62].
Table 1 Limits of quantification (LQ) for the elements determined

\begin{tabular}{llllll}
\hline & $\mathbf{C d}$ & $\mathrm{Cr}$ & $\mathrm{Pb}$ & $\mathrm{Hg}$ & $\mathbf{N}$ \\
\hline $\mathrm{LQ}^{\mathrm{a}}$ & 0.05 & 0.05 & 1.00 & 0.020 & 0.01 \\
\hline${ }^{\mathrm{a}} \mathrm{ln} \mathrm{mg} / \mathrm{kg}(\mathrm{HM})$ and mass-\% (N) & & &
\end{tabular}

Table 2 Statistical values for determination of nitrogen in reference materials during the measurement period

\begin{tabular}{lrlll}
\hline & References & \multicolumn{2}{l}{ Measurements } & \multirow{2}{*}{ RR (\%) } \\
\cline { 3 - 4 } & MV \pm SD & MV \pm SD & RSD (\%) & \\
\hline Carbamide & $46.62 \pm 2.33$ & $47.05 \pm 0.81$ & 1.7 & 100.9 \\
Glutamic acid & $9.52 \pm 0.95$ & $9.58 \pm 0.18$ & 1.9 & 100.7 \\
TBK6 & $0.156 \pm 0.01$ & $0.16 \pm 0.01$ & 5.8 & 103.5 \\
\hline
\end{tabular}

$M V \pm S D$ mean value \pm standard deviation (in $\mathrm{mg} / \mathrm{kg}$ ), $R S D$ relative standard deviation, $R R$ recovery rate, related to the reference, TBK6 Kinesin-like polypeptides 6

Table 3 Statistical values for determinations of heavy metals in reference materials during the measurement period

\begin{tabular}{lllll}
\hline & References & \multicolumn{2}{l}{ Measurements } & RR (\%) \\
\cline { 3 - 4 } & MV \pm SD & MV \pm SD & RSD (\%) & \\
\hline $\mathrm{Cd}$ & $0.04 \pm 0.004$ & $0.040 \pm 0.001$ & 1.7 & 100.7 \\
$\mathrm{Cr}$ & $0.04 \pm 0.004$ & $0.041 \pm 0.001$ & 2.3 & 101.8 \\
$\mathrm{~Pb}$ & $0.04 \pm 0.004$ & $0.041 \pm 0.001$ & 1.9 & 101.3 \\
$\mathrm{Hg}$ & $2 \pm 0.2$ & $2.033 \pm 0.054$ & 2.7 & 101.7 \\
\hline
\end{tabular}

$M V \pm S D$ mean value \pm standard deviation (in $\mathrm{mg} / \mathrm{L}, \mu \mathrm{g} / \mathrm{L}$ for $\mathrm{Hg}$ ), $R S D$ relative standard deviation, $R R$ recovery rate, related to the reference

\section{Results}

\section{Quality control of measurement}

The limits of quantitative detection of elements in moss specimens (Table 1) are within the ranges of the reference materials indicated in Tables 2, 3, 4. Similar results are shown in the quality control for $\mathrm{Al}, \mathrm{As}, \mathrm{Cu}, \mathrm{Fe}, \mathrm{Ni}, \mathrm{Sb}$, $\mathrm{V}$ and $\mathrm{Zn}$ (Additional file 1: Tables S1-S3).

The element concentrations for M2 and M3 measured in this research did not differ significantly from the respective reference values $(\mathrm{RR} \%<10 \%)$, with the exception of $\mathrm{Cr}(14 \%, \mathrm{M} 3)$. This means that the recovery rate mainly was above $90 \%$ (Table 4). All measurements of elements concentrations in M2 and M3 with the exception of $\mathrm{Zn}$ (M2) were within the ranges published by Harmens et al. [12] and Steinnes et al. [66] (Table 4). 
Table 4 Statistical values of the moss reference materials M2 and M3

\begin{tabular}{|c|c|c|c|c|c|c|c|c|}
\hline & \multirow{2}{*}{$\begin{array}{l}\text { M2 } \\
\text { Reference }\end{array}$} & \multicolumn{2}{|l|}{$M 2^{\mathrm{a}}$} & \multirow[t]{2}{*}{ RR (\%) } & \multirow{2}{*}{$\begin{array}{l}\text { M3 } \\
\text { Reference }\end{array}$} & \multicolumn{2}{|l|}{$M 3^{a}$} & \multirow[t]{2}{*}{ RR (\%) } \\
\hline & & $M V \pm S D$ & RSD (\%) & & & $M V \pm S D$ & RSD (\%) & \\
\hline $\mathrm{Cd}$ & $0.454 \pm 0.019$ & $0.44 \pm 0.01$ & 1.8 & 97.2 & $0.106 \pm 0.005$ & $0.101 \pm 0.01$ & 5.6 & 95.6 \\
\hline $\mathrm{Cr}$ & $0.97 \pm 0.17$ & $0.89 \pm 0.07$ & 7.6 & 92.2 & $0.67 \pm 0.19$ & $0.58 \pm 0.06$ & 11.3 & 86.0 \\
\hline $\mathrm{Pb}$ & $6.37 \pm 0.43$ & $6.54 \pm 0.2$ & 3.6 & 102.6 & $3.33 \pm 0.25$ & $3.41 \pm 0.09$ & 2.7 & 102.3 \\
\hline $\mathrm{Hg}$ & $0.058 \pm 0.005$ & $0.057 \pm 0.001$ & 1.8 & 99.0 & $0.035 \pm 0.004$ & $0.037 \pm 0.006$ & 16.0 & 105.7 \\
\hline
\end{tabular}

$M V \pm S D$ mean value \pm standard deviation (in $\mathrm{mg} / \mathrm{L}, \mu \mathrm{g} / \mathrm{L}$ for $\mathrm{Hg}$ ), $R S D$ relative standard deviation, $R R$ recovery rate, related to the reference

a Measurements

\section{Geostatistically analysed, modelled and mapped spatial structures of element concentrations in moss 1990-2015} The presentation of results of geostatistical analysis, modelling and mapping explained in "Descriptive statistics" section focus on those elements relevant for CLRTAP, i.e. $\mathrm{Cd}, \mathrm{Hg}, \mathrm{Pb}$ and $\mathrm{N}$ and on $\mathrm{Cr}$ representing those three elements which did not show a continuous decrease between 1990 and 2015 but an intermediate increase from 2000 to 2005 (Cr, Sb, Zn). Thereby, the results derived from the moss sampling 2015 are compared to those from previous campaigns. In addition, geostatistical surface estimations of $\mathrm{Al}, \mathrm{As}, \mathrm{Cu}, \mathrm{Fe}, \mathrm{Ni}, \mathrm{Sb}, \mathrm{V}$ and $\mathrm{Zn}$ concentrations in moss and respective statistical values are provided in the supplement (Additional file 1: Figures S1-S4; Tables S4 and S5).

\section{Cadmium}

The GMS 2015 yielded $398 \mathrm{Cd}$ measurement values which were analysed by application of statistical methods explained in "Methods" section. With values between 0.035 and $1.760 \mathrm{mg} / \mathrm{kg}$ Plesch shows lower 20th, 50th, 90th and 98th percentiles than Hypcup and Psepur [62]. Regarding the federal states, Cd concentrations in North Rhine-Westphalia show the highest median value $(0.189 \mathrm{mg} / \mathrm{kg})$. The $\mathrm{Cd}$ median of the federal states Hesse, Mecklenburg-Western Pomerania, Saarland, Saxony and Thuringia exceeds the Germany-wide median $(=0.136 \mathrm{mg} / \mathrm{kg} \mathrm{Cd})$. The lowest $\mathrm{Cd}$ median below the 20th percentile $(=0.0944 \mathrm{mg} / \mathrm{kg})$ was found in Hamburg $(=0.089 \mathrm{mg} / \mathrm{kg})[62]$.

Due to skewness $(\mathrm{Sk}=6.28)$, $\mathrm{Cd}$ measurement values 2015 were transformed (Box Cox) before spatial generalisation by Universal Kriging. The spherical variogram model shows a low, but significant autocorrelation with a range of $223 \mathrm{~km}$ and a nugget-to-sill ratio of 0.66 . Due to the high nugget effect, there is a considerable smoothing of the estimated values' map. The results of cross-validation indicate a rather unbiased spatial estimation $(\mathrm{MSE}=-0.07$; RMSSE $=1.2$ ) with low correlations between measurements and estimations $\left(r_{\mathrm{p}}=0.22\right)$. The MPEc accounts for $12.55 \%$. Figure 2 depicts increased $\mathrm{Cd}$ concentrations from North Rhine-Westphalia to Saxony. Further the maps show the trends of $\mathrm{Cd}$ accumulation in moss specimens collected between 1990 and 2015. During this period, the Germany-wide median of Cd concentrations decreased by $52.5 \%$. Between 1990 and 1995 the median Cd accumulation in moss increased by $+2.1 \%$, and from 1995 to 2005 it decreased by $-28.3 \%$. No changes of the median Cd values throughout Germany could be measured between 2000 and 2005, while from 2005 to 2015 the median $\mathrm{Cd}$ concentrations in moss decreased significantly by $-35.2 \%$. Above-average decreased values were found between 2005 and 2015 in Baden-Wuerttemberg $(-35.8 \%)$, North Rhine-Westphalia $(-40 \%)$, Rhineland Palatinate (-57.3\%), Schleswig-Holstein $(-41.3 \%)$ and Saxony-Anhalt $(-37.4 \%)$. No increase of median $\mathrm{Cd}$ concentrations could be detected during the years 2005 to 2015 [38].

\section{Chromium}

The moss survey 2015 yielded $\mathrm{Cr}$ measurements from 399 sites with values ranging between 0.051 and $4.951 \mathrm{mg} / \mathrm{kg}$. Hypсup exhibited higher 20th, 50th, 90th and 98th percentile values than Plesch and Psepur. Accordingly, the highest value in Germany $(4.951 \mathrm{mg} /$ $\mathrm{kg}$ ) was found in a Hypcup sample in Baden-Wuerttemberg (BW450). Spatial clusters of values in this magnitude can be found in North Rhine-Westphalia (Ruhr Region), along the upper Rhine Valley (Baden-Wuerttemberg), in north and central Hesse, in Saxony-Anhalt and Saxony as well as in Bavaria, Lower Saxony and Saarland. The values in Brandenburg, Hesse, Hamburg, Lower Saxony, North Rhine-Westphalia, Rhineland Palatinate and Saarland are above the Germany-wide $\mathrm{Cr}$ median value $(=0.57 \mathrm{mg} / \mathrm{kg})$. The lowest median $\mathrm{Cr}$ concentration was found in Mecklenburg-Western Pomerania $(=0.34 \mathrm{mg} / \mathrm{kg})$.

The geostatistical surface estimation of $\mathrm{Cr}$ concentrations was performed by application of Ordinary Kriging. 
Due to skewness $(S k=3.17)$, the data were Box-Coxtransformed. An exponential model variogram was fitted to the empirical variogram indicating a low but significant $(p<0.01)$ spatial autocorrelation with a range of $104 \mathrm{~km}$ and a nugget/sill ratio of 0.67 . The cross-validation proved a low bias (MSE $=-0.01$; $\mathrm{RMSSE}=0.96$ ), and the MPEc accounted for $20.38 \%$.

Figure 3 presents the temporal and spatial development of $\mathrm{Cr}$ accumulation from 1990 to 2015. The maps corroborate a comprehensive decrease of $\mathrm{Cr}$ concentrations throughout Germany. From 2000 to 2005, the values increased remarkably.

From 2000 to 2005, the $\mathrm{Cr}$ concentrations in moss increased. Hot spots can be found in the Ruhr Region (North Rhine-Westphalia), in the North-West of Lower Saxony, Saxony, Saxony-Anhalt and in MecklenburgWestern Pomerania. From 2005 to 2015, the Cr accumulation in moss specimens decreased clearly.

The significant decrease of $\mathrm{Cr}$ median values between 1990 and 2000 accounted for $58.5 \%$ throughout Germany. However, from 2000 to 2005 the German $\mathrm{Cr}$ median increased by $+159.3 \%(p>0.05)$. The highest rise was found in Mecklenburg-Western Pomerania (+754.5\%). From 2005 and 2015, the reduction was $75.8 \%$ and between 1990 and 2015 it accounted for 74\% [38].

\section{Mercury}

In 2015, $397 \mathrm{Hg}$ measurements ranged between $0.0047 \mathrm{mg} / \mathrm{kg}$ and $0.1960 \mathrm{mg} / \mathrm{kg}$. Regarding the 20th, 50th, 90th and 98th percentile values, there are no striking differences between the moss species.

Since the $\mathrm{Hg}$ measurements were skewed $(\mathrm{Sk}=3.33)$, they were Box-Cox-transformed, then interpolated by means of Ordinary Kriging, and finally back transformed. For the spherical autocorrelation function fitted to the experimental variogram autocorrelation is weak but could be proved to be statistically significant with a sill of $67 \mathrm{~km}$ and a nugget-to-sill ratio of 0.63 . Cross-validation indicates a rather low bias $(\mathrm{MSE}=-0.02$; $\mathrm{RMSSE}=1.37)$ with correlations of measurements and estimated values $\left(r_{\mathrm{p}}=0.33\right)$. The mean relative corrected deviance between empiric measurements and geostatistically estimated values is low $(\mathrm{MPEc}=5.21 \%)$.

The Kriging maps in Fig. 4 depict the spatial and temporal trends of $\mathrm{Hg}$ bioaccumulation in moss due to atmospheric deposition between 1995 and 2015. The values are low in terms of the European classification of measurement values to be applied. From 1995 to 2000, slight increases can be proved in the Eastern part of Schleswig-Holstein, in the South of Saxony-Anhalt, Northern Thuringia, and in Baden-Wuerttemberg. Largearea $\mathrm{Hg}$ bioaccumulation occurred in North RhineWestphalia. During 2000 to 2005, further decline of $\mathrm{Hg}$ concentrations in moss occurs throughout Germany. From 2005 to 2015, the $\mathrm{Hg}$ accumulation decreased in regions located in Bavaria, North Rhine-Westphalia, Saxony, Saxony-Anhalt, Mecklenburg-Western Pomerania. Contrary to that trend, increases of $\mathrm{Hg}$ concentrations could be localised in Lower Saxony. During 1990 to 2015, the Rhine valley in Baden-Wuerttemberg, Northern Thuringia, in the Erz Mountains (Saxony) and in Mecklenburg-Western Pomerania are regions with continuous enhanced values.

In 2015, the 98th percentile of $\mathrm{Hg}$ concentrations in moss amounted to $0.0702 \mathrm{mg} / \mathrm{kg}$, the 90 th percentile to $0.054 \mathrm{mg} / \mathrm{kg}$, and the median throughout Germany was $0.0446 \mathrm{mg} / \mathrm{kg}$ ). The medians measured from 1995 to 2000 increased significantly in Baden-Wuerttemberg, Rhineland Palatinate, Saxony-Anhalt and Thuringia. Across Germany, no such statistically significant trend could be corroborated. From 2000 to 2005, the median of $\mathrm{Hg}$ measurements sank in almost all federal states, and the median decreased by $14.6 \%$, and during 2005 to 2015 the median values of $\mathrm{Hg}$ concentrations in moss accounted for another $4 \%(p<0.05)$. Since 2005 , the trends of $\mathrm{Hg}$ bioaccumulation were as follows: Increases could be proved for Brandenburg (+27.8\%) and Lower Saxony, $(+14.8 \%)$, while reductions were measured in Bavaria, $(-18.2 \%)$, North Rhine-Westphalia $(-25.8 \%)$, Rhineland Palatinate $(-5.7 \%)$ and Saxony $(-13.7 \%)$. The trend between 1995 and 2015 is characterised by a significant reduction throughout Germany by $20 \%$, while spatial differences in terms of federal states range between $-51.2 \%$ (Bavaria) and $+17.4 \%$ (Brandenburg). Hesse, Hamburg, Lower Saxony, Rhineland Palatinate, Schleswig-Holstein, Saarland, Saxony-Anhalt and Thuringia did not show any significant decline since 1995 [38].

\section{Lead}

The GMS 2015 yielded Pb concentrations in moss collected at 400 sites across Germany ranging from $0.47 \mathrm{mg} /$ $\mathrm{kg}$ to $19.34 \mathrm{mg} / \mathrm{kg}$. In Hypcup, the 20th, 50th and 90th percentile values exceeded the values found in Psepur and Plesch. The 98th percentile accounted for $9.094 \mathrm{mg} / \mathrm{kg}$ and the 90 th percentile for $4.334 \mathrm{mg} / \mathrm{kg}$. Baden-Wuerttemberg, Hamburg, North Rhine-Westphalia, SchleswigHolstein, Saarland and Saxony exceed the Germany-wide median $(1.830 \mathrm{mg} / \mathrm{kg})$. Lowest medians of measured $\mathrm{Pb}$ concentrations were found in Bavaria, MecklenburgWestern Pomerania and Saxony-Anhalt. The Germanywide trend of median $\mathrm{Pb}$ bioaccumulation exhibits a continuous decrease throughout time (1990-2015). A similar tendency could be found for most of the federal states. It was only Hesse (2000-2005: +8\%) and Hamburg (1990-1995: +12.3\%, and 2005-2015: +20.4\%), whereby these trends were not statistically significant. 


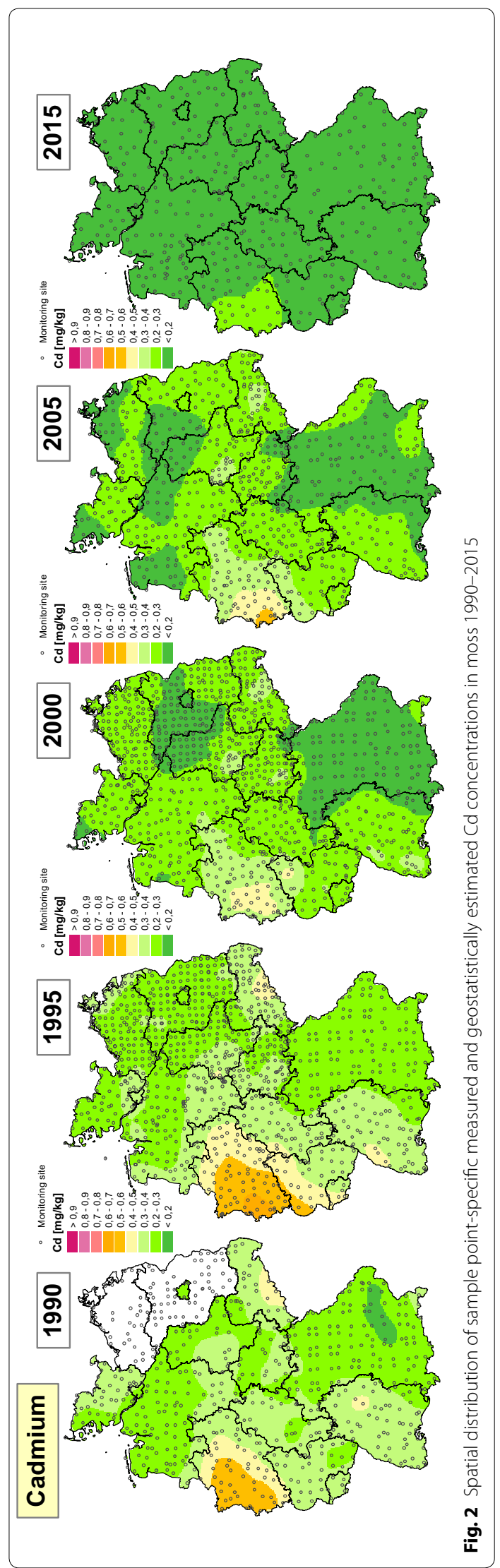




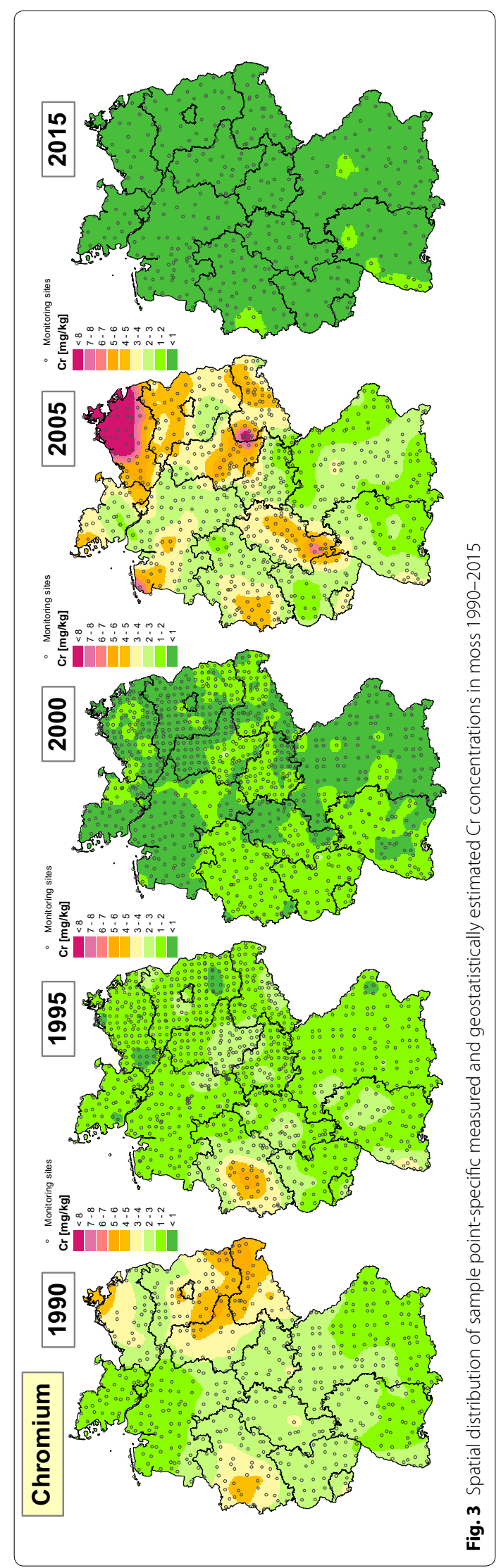




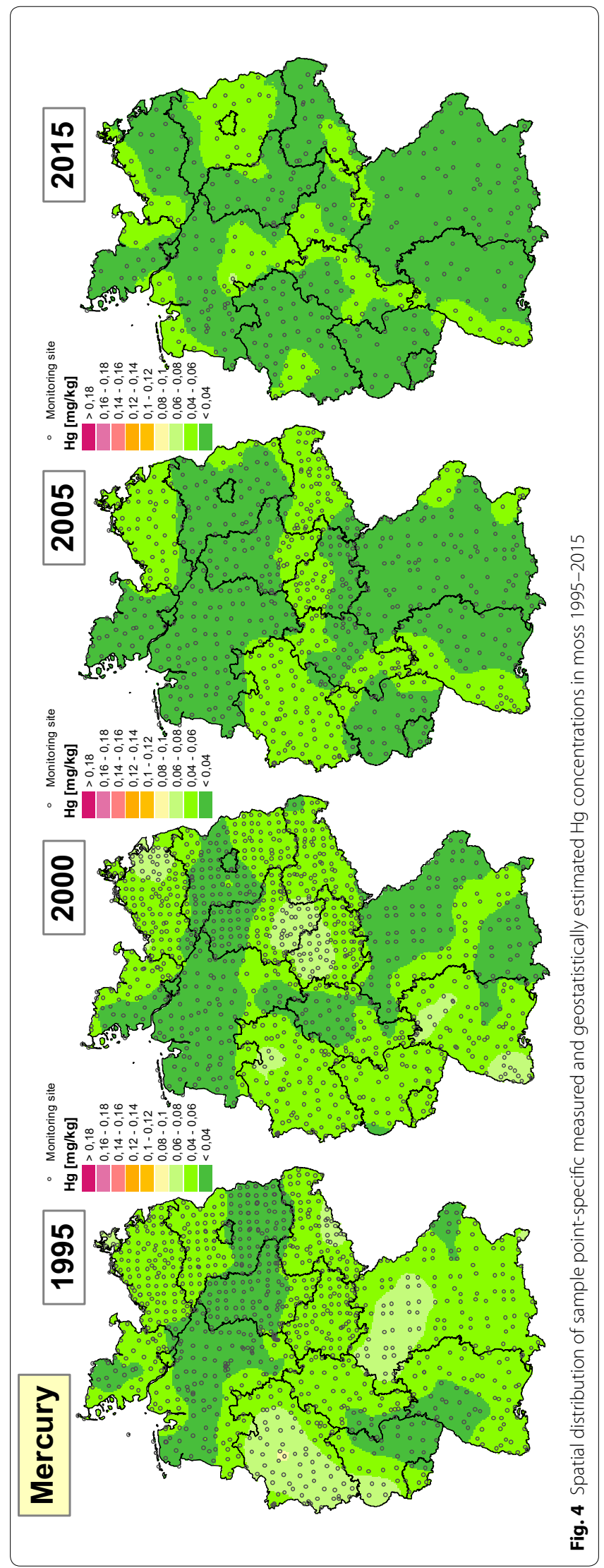


The decrease of $\mathrm{Pb}$ concentrations in moss trends collected in the federal states during 1990-2015 was statistically significant with the exception of Hamburg $(n=3)$ and ranged between $-81.3 \%$ (Schleswig-Holstein) and $-92.1 \%$ (Saxony) [38].

The spatial estimation and surface covering mapping of $\mathrm{Pb}$ bioaccumulation were calculated by Ordinary Kriging from Box-Cox-transformed data. The original measurement data were clearly skewed $(\mathrm{Sk}=4.42)$. The exponential model variogram indicated a low but significant spatial autocorrelation with a range amounting to $202 \mathrm{~km}$ and a nugget-to-sill ratio of 0.70 . The MSE $(=-0.04)$ proved a rather unbiased estimation and the RMSSE $(=1.24)$ points out an overestimation. The correlation between measurements and estimations was $r_{\mathrm{p}}=0.28$ and the MPEc was $23.9 \%$.

The Kriging map for the GMS 2015 (Fig. 5) is covered with estimated $\mathrm{Pb}$ concentrations $<5 \mathrm{mg} / \mathrm{kg}$. Within this range, regions with estimation $>2.62 \mathrm{mg} / \mathrm{kg}$ are located in Hamburg and around (Schleswig-Holstein), in Lower Saxony (Harz mountains), in Saxony, in the Rhine valley (Baden-Wuerttemberg) and in North Rhine-Westphalia.

Figure 5 also depicts the spatial and temporal development of $\mathrm{Pb}$ concentrations from 1990 to 2015. The maps prove a Germany-wide continuous decrease of $\mathrm{Pb}$ bioaccumulation. The most distinct decline was proved for North Rhine-Westphalia, Brandenburg (Southern regions) and Saxony (Lausitz and Erz Mountains).

\section{Nitrogen}

From the measured concentrations of $\mathrm{N}$ in 400 moss specimens, ranging between 0.80 and $3.49 \%$, a median value of $1.431 \%$ was computed. Regarding all descriptive statistical measures computed, Psepur evidenced the highest values. The highest $\mathrm{N}$ concentration was found in Mecklenburg-Western Pomerania. $\mathrm{N}$ measurements exceeding the 90 th percentile $(=2.131 \%)$ could only be found in Mecklenburg-Western Pomerania, SchleswigHolstein, Lower Saxony, North Rhine-Westphalia and Hesse. Ranking the German federal states by $\mathrm{N}$ concentrations accumulated in moss, Mecklenburg-Western Pomerania shows the highest median value $(=2.370 \%)$, followed by North Rhine-Westphalia, Lower Saxony, Hesse, Thuringia, Schleswig-Holstein and Saxony, all exceeding the Germany-wide median $\mathrm{N}$ concentration in moss. The lowest median $N$ values were found for Hamburg and Saarland (1.190\% and 1.115\%, respectively).

The geostatistical estimation of surface covering $\mathrm{N}$ concentration in moss was performed by using secondorder Universal Kriging of log-transformed measurement values. The spherical model variogram fitted to the experimental one corroborates a slight but significant spatial autocorrelation with a range of $117 \mathrm{~km}$ and a nugget-to-sill ratio of 0.67 . However, the estimation is nearly unbiased $(\mathrm{MSE}=-0.03$; $\mathrm{RMSSE}=0.97$ ) with low differences between measured and estimated values $(\mathrm{MPEC}=2.96 \%)$ which are correlated with $r_{\mathrm{p}}=0.57$.

Within the spatial patterns depicted in Fig. 6, the highest surface estimations with values $>2.4 \%$ cover most of the territory of Mecklenburg-Western Pomerania. Estimations between 2.2 and $2.4 \%$ can be observed in Lower Saxony and North Rhine-Westphalia, especially in the western regions close to the border between both German federal states and the Netherlands. $\mathrm{N}$ concentrations $>1.6 \%$ cover wide areas of Schleswig-Holstein, Hesse, Thuringia and Saxony. N concentrations $<1.0 \%$ occur dominantly in the Alps.

The Kriging maps for 2005 and 2015 shown in Fig. 6 indicate that the $\mathrm{N}$ bioaccumulation did not change significantly during the last 10 years. However, this Germany-wide statistical statement includes regional decreases in Bavaria and Baden-Wuerttemberg and increases in Lower Saxony, Hamburg and in Mecklenburg-Western Pomerania. Permanent $\mathrm{N}$ hot spots existed between 2005 and 2015 in North Rhine-Westphalia and Mecklenburg-Western Pomerania. Inference statistical tests corroborate that the $\mathrm{N}$ concentrations did not change significant between 2005 and 2015 neither Germany-wide nor in most of the federal states. Significant increases were proved for Hamburg $(-33.1 \%)$, Mecklenburg-Western Pomerania $(-30.4 \%)$ and Bavaria $(-13.9 \%)$. Significant decreases of $\mathrm{N}$ concentrations in moss were determined for Baden-Wuerttemberg $(-13.9 \%)$.

\section{Discussion}

To evaluate the results presented, the discussion includes not only the elements presented in this article $(\mathrm{Cd}, \mathrm{Cr}$, $\mathrm{Hg}, \mathrm{Pb} ; \mathrm{N}$ ) but also some of those which could not be tackled. The spatial patterns of $\mathrm{As}, \mathrm{Cd}, \mathrm{Ni}, \mathrm{Pb}, \mathrm{Sb}$ and $\mathrm{Zn}$ detected in the GMS 2015 were rather similar to those mapped for the GMS 1995, 2000 and 2005. This similarity was quantified by means of Pearson correlation between the respective Kriging maps which accounted in case of As, Ni and Sb for $r_{\mathrm{P}}>0.4$ (exceptions: As 2000, Sb 1995) and in case of $\mathrm{Cd}, \mathrm{Pb}$ and $\mathrm{Zn}$ for $r_{\mathrm{p}}>0.6$. Continuous hot spots existed in the industrialised regions of North Rhine-Westphalia (mainly $\mathrm{Cd}, \mathrm{Cr}, \mathrm{Cu}, \mathrm{Fe}, \mathrm{Hg}, \mathrm{Pb}, \mathrm{Sb}, \mathrm{V}$ and $\mathrm{Zn}$ ), in the Rhine-Main Region (primarily $\mathrm{Cd}, \mathrm{Cr}, \mathrm{Cu}$ and $\mathrm{Zn}$ ), in the industrialised region Halle/Leipzig (especially $\mathrm{Cd}, \mathrm{Cu}, \mathrm{Fe}, \mathrm{V}$ and $\mathrm{Zn}$ ), in Saarland (most notably $\mathrm{Al}, \mathrm{Cd}, \mathrm{Cr}, \mathrm{Fe}, \mathrm{Pb}, \mathrm{V}$ and $\mathrm{Zn}$ ), in Saxony (particularly As, $\mathrm{Cd}, \mathrm{Fe}, \mathrm{Hg}, \mathrm{Pb}$ and $\mathrm{Sb}$ ), in Mecklenburg-Western Pomerania (first of all $\mathrm{u}, \mathrm{Fe}, \mathrm{Hg}$ and $\mathrm{Zn}$ ), in the Harz Mountains (above all $\mathrm{Cd}, \mathrm{Pb}$ and $\mathrm{Zn}$ ), in the Black forest (in the first 


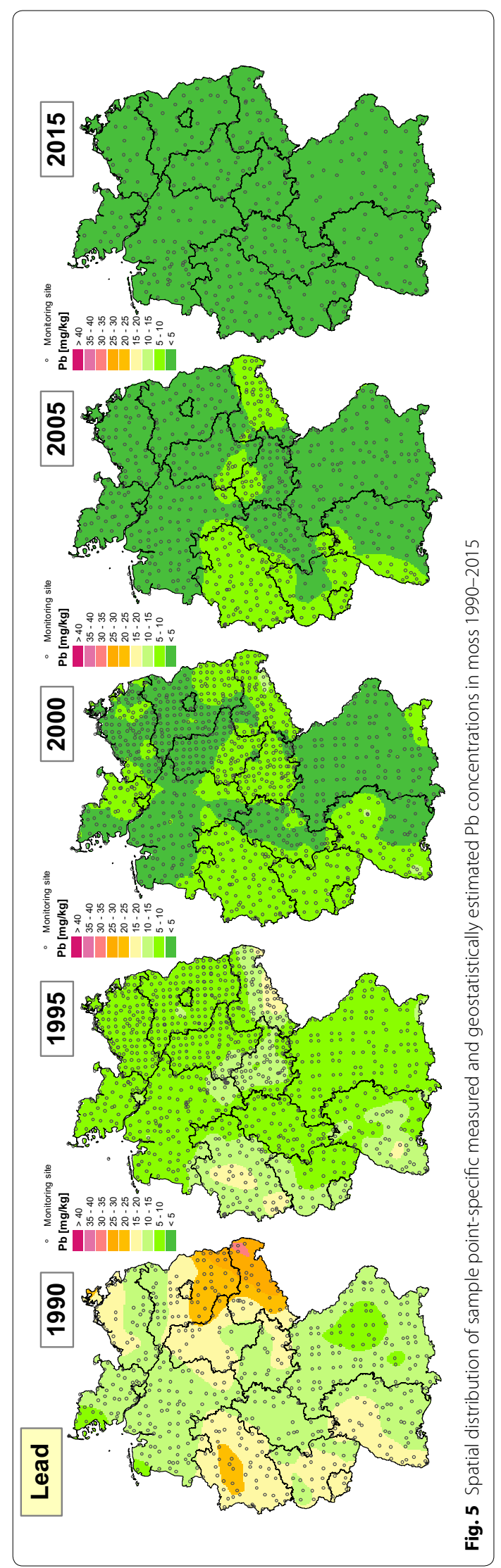




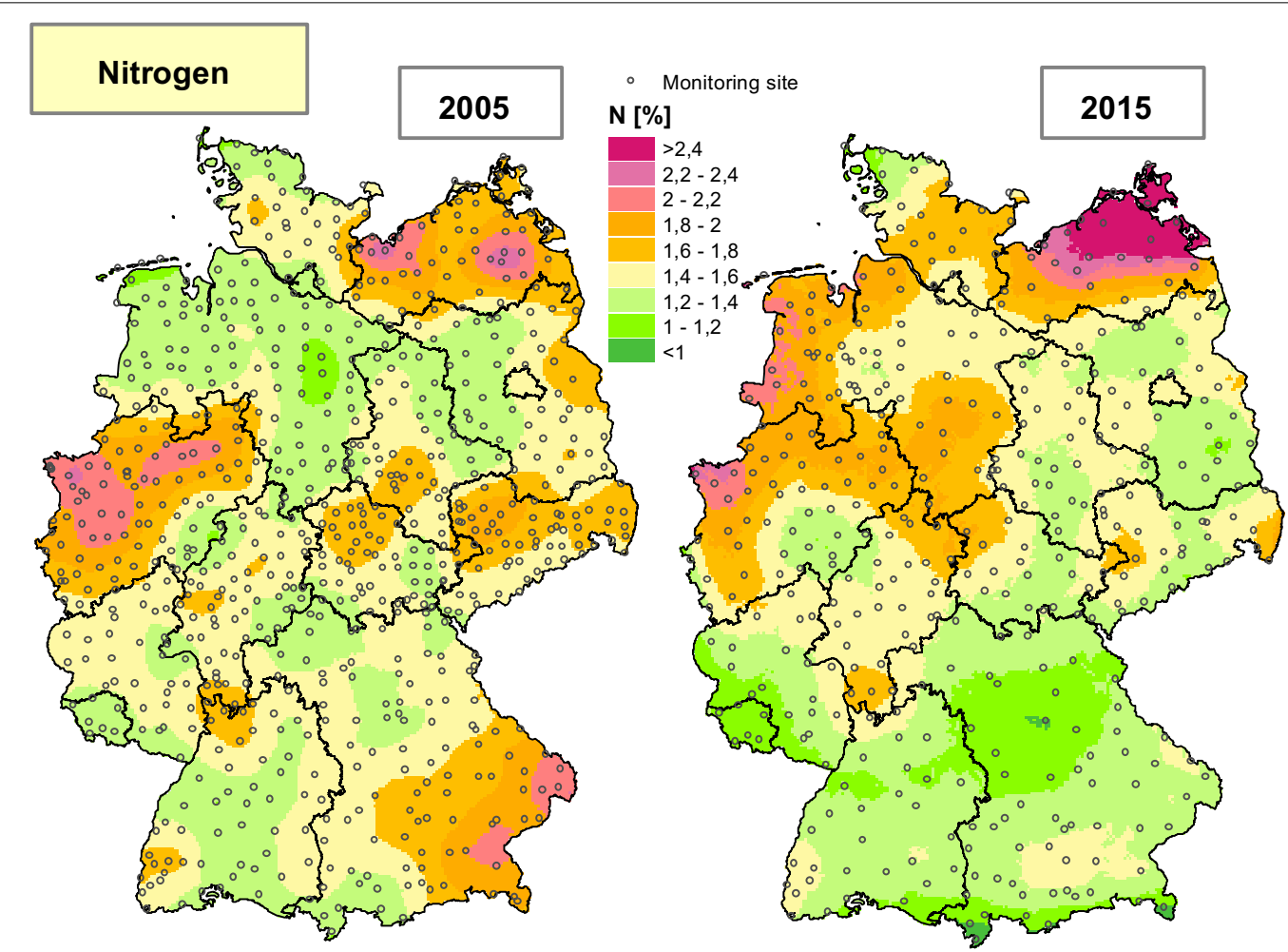

Fig. 6 Spatial distribution of sample point-specific measured and geostatistically estimated N concentrations in moss 2005-2015

instance $\mathrm{Pb}, \mathrm{Sb}$ ), in the upper Rhine valley (mainly $\mathrm{Al}, \mathrm{As}$, $\mathrm{Cr}, \mathrm{Fe}$ and $\mathrm{Hg}$ ) and in Berlin (primarily $\mathrm{Cr}$ and $\mathrm{Zn}$ ).

The development of bioaccumulation of heavy metals since 2005 is characterised by a Germany-wide significant decrease $(p<0.05)$. This general trend varies by element and region in terms of federal state. The range of decrease was between $-4 \%(\mathrm{Hg})$ to $-75.8 \%(\mathrm{Cr})$. Similar was the trend from the first measurement and 2015: The median values of heavy metals decreased significantly since 1990 and of $\mathrm{Al}, \mathrm{Hg}$ and $\mathrm{Sb}$ since 1995. The most distinct decrease was determined for $\mathrm{Pb}(-85.9 \%)$, the lowest for $\mathrm{Hg}(-20 \%)$. These trends of bioaccumulation are in agreement with the heavy metal emissions in Germany between 1990 and 2015 [30], especially in case of As, Cd, $\mathrm{Ni}$ and $\mathrm{Pb}$. The concentrations of these four heavy metals in moss collected in 2005 on the one hand and modelled atmospheric deposition on the other hand were correlated with $r_{\mathrm{S}}>0.3$ [38, 50,51]. According to NaSE [30] emissions from metallurgy $(\mathrm{Cd}, \mathrm{Ni}$ and $\mathrm{Pb})$, power economy (As, $\mathrm{Cd}, \mathrm{Ni}$ and $\mathrm{Pb}$ ), manufacturing and constructing industry ( $\mathrm{As}, \mathrm{Ni}$ and $\mathrm{Pb})$ and traffic $(\mathrm{Pb})$ declined since 1990. However, the decrease of $\mathrm{Hg}$ bioaccumulation is less than the reduction of $\mathrm{Hg}$ emissions [30]. This is possibly due to long-range transport of gaseous $\mathrm{Hg}$ and atmospheric residence times of 6 to 18 months [52]. The concentrations of $\mathrm{Cu}$ and $\mathrm{Zn}$ in moss contradict the emission trends. At least for $\mathrm{Zn}$, the correlation between the concentration in moss ample in 2005 and the modelled atmospheric deposition is $r_{\mathrm{s}}<0.3$ [38].

For $\mathrm{Cr}$, good agreement could be identified between the emission trends [30] and the concentrations in moss during the period 1990 to 2015. Strikingly, the Cr concentrations in moss were extraordinarily high in 2005, especially in Mecklenburg-Western Pomerania and conurbations such as Bremen, Hamburg, Dresden, Halle/ Leipzig and the Ruhr region. Respective increased values were also reported from Austria and were attributed to a Cr mine on the Kola Peninsula [23, 38].

The spatial pattern of $\mathrm{N}$ concentrations in moss specimens collected in 2015 is in a more distinctive agreement than those determined in 2005 with what could be expected from the spatial patterns of potential emission sources: Regions with high spatial livestock density as for instance the Northwestern part of Lower Saxony and North Rhine-Westphalia show high $\mathrm{N}$ bioaccumulation and corroborate other investigations [26, 28, 29, 54]. The $\mathrm{N}$ emissions between 2005 and 2015 declined by $23.9 \%$ in case of $\mathrm{NO}_{\mathrm{x}}$ emissions. In 2015, agricultural land use emitted $95 \%$ of the $\mathrm{NH}_{3}$ in Germany which increased between 2005 and 2015 by 12\% [31]. In conclusion, this should be evidenced by quantitatively correlating the spatial livestock density with the Kriging maps. Further, it 
should be investigated whether the replacement of Plesch through the more nitrophilous Psepur could be a relevant influence.

\section{Conclusions}

The maps given in Figs. 2, 3, 4, 5, 6 are based on an international classification [16] which does not allow detailing much regional variance due to decreasing element concentrations in moss. Therefore, element- and campaign-specific percentile statistics should be computed ensuring to map the still existing spatial variance of element concentrations statistically sound. Based on this, heavy metals integrating Multi Metal Index should be computed and mapped according to Pesch and Schröder $[42,43,44]$ and Schröder and Pesch [56-60] allowing to comprehend the many data collected from 1990 to 2015, to integrate several elements in one map depicting their spatial patterns according to their percentile statistics and not according to the international classification [16].

\section{Additional file}

Additional file 1: Table S1. Limits of quantification $(L Q)$ for the elements determined. Table S2. Statistical values for determinations of heavy metals in reference materials during the measurement period. Table $\mathbf{S 3}$. Statistical values of the moss reference materials M2 and M3. Table S4a. Geostatistical analysis 2015: Methods and parameters of the model. Table S4b. Geostatistical analysis 2015: Quality parameters of the model. Figure S1. Spatial distribution of sample point-specific measured and geostatistically estimated concentrations of Al and As in moss. Figure $\mathbf{S 2}$. Spatial distribution of sample point-specific measured and geostatistically estimated concentrations of Cu and Fe in moss. Figure S3. Spatial distribution of sample point-specific measured and geostatistically estimated concentrations of $\mathrm{Ni}$ and $\mathrm{Sb}$ in moss. Figure S4. Spatial distribution of sample point-specific measured and geostatistically estimated concentrations of $V$ and $Z n$ in moss. Table S5. Spatial distribution of sample pointspecific measured and geostatistically estimated $V$ and $Z n$ concentrations in moss.

\section{Abbreviations}

AAS: atomic absorption spectroscopy; Al: aluminium; As: arsenic; BB: Brandenburg; BE: Berlin; BW: Baden-Wuerttemberg; BY: Bavaria; Cd: cadmium; CLRTAP: convention on long-range transboundary air pollution; Cr: chromium; Cu: copper; CV: coefficient of variation; EMEP: European Monitoring and Evaluation Programme; EMS: European moss survey; Fe: iron; GMS: German moss surveys; HE: Hesse; Hg: mercury; HH: Hamburg; HM: heavy metals; Hypcup: Hypnum cupressiforme; ICP: International Cooperative Programme; ICP-MS: inductively coupled plasma-mass spectrometry; ISO: International Organization for Standardization; LQ: limit of quantification; M2, M3: moss reference materials; ME: mean error; MPE: median of percentage errors; MPEc: corrected mean percentage error; MSE: mean standardized error; MV: Mecklenburg-Western Pomerania; MV: mean value; $\mathrm{N}$ : nitrogen; $\mathrm{n}$ : sample size; $\mathrm{NH}_{3}$ : ammonia; $\mathrm{Nl}$ : lower Saxony; Ni: nickel; $\mathrm{NO}_{x}$ : nitrogen oxide; NW: North Rhine-Westphalia; p: level of significance; Pb: lead; Plesch: Pleurozium schreberi; POP: persistent organic pollutants; Psepur: Pseudoscleropodium purum; QC: quality control; RMSSE: root mean square standardised error; RP: Rhineland Palatinate; $r_{\mathrm{p}}$ : correlation coefficient (Pearson); RR: recovery rate; $r_{s}$ : correlation coefficient (Spearman); RSD: relative standard deviation; Sb: antimony; SD: standard deviation; SH: Schleswig-Holstein; Sk: skewness; SL: Saarland; SN: saxony; ST:
Saxony-Anhalt; TBK6: kinesin-like polypeptides 6; TH: Thuringia; UNECE: United Nations Economic Commission for Europe; V: vanadium; Zn: zinc.

\section{Acknowledgements}

This research paper was only possible through the help and support of the Federal Environmental Agency, Dessau-Roßlau, Germany.

\section{Authors' contributions}

WS headed the computations executed by SN. WS wrote the article. All authors read and approved the final manuscript.

\section{Funding}

Federal Environmental Agency, Dessau-Roßlau, Germany.

\section{Availability of data and materials}

The datasets generated and/or analysed during the current study are not publicly available due to copyright but are available from the corresponding author on reasonable request.

\section{Ethics approval and consent to participate}

Not applicable.

\section{Consent for publication}

Not applicable.

\section{Competing interests}

The authors declare that they have no competing interests.

Received: 27 March 2019 Accepted: 15 May 2019

Published online: 27 May 2019

\section{References}

1. Aas W, Breivik K (2009) Heavy metals and POP measurements 2007. EMEP/CCC-Report 3/2009. Norwegian Institute for Air Research, Kjeller, Norway. https://www.nilu.no/projects/ccc/reports/cccr3-2009.pdf. Accessed 31 Jan 2019

2. Balla S, Uhl R, Schlutow A, Lorentz H, Förster M, Becker C (2013) Untersuchung und Bewertung von straßenverkehrsbedingten Nährstoffeinträgen in empfindliche Biotope. https://www.bast.de/BASt_2017/DE/Verke hrstechnik/Publikationen/Download-Publikationen/Downloads/N-Naehr stoffeintrag.pdf. Accessed 31 Jan 2019

3. Bill R (2010) Grundlagen der Geoinformationssysteme. 5., völlig neu bearbeitete Auflage. Wichmann Verlag, Heidelberg

4. Bobbink R, Hicks K, Galloway J, Spranger T, Alkemade R, Ashmore M, Bustamante M, Cinderby S, Davidson E, Dentener F, Emmett B, Erisman JW, Fenn M, Gilliam F, Nordin A, Pardo L, De Vries W (2010) Global assessment of nitrogen deposition effects on terrestrial plant diversity: a synthesis. Ecol Appl 20:30-59

5. Calmano W (2001) Untersuchung und Bewertung von Sedimenten: ökotoxikologische und chemische Testmethoden. Springer, Berlin Heidelberg

6. Colette A, Aas W, Banin L, Braban C F, Ferm M, González Ortiz A, lyin I, Mar K, Pandolfi M, Putaud JP, Shatalov V, Solberg S, Spindler G, Tarasova O, Vana M, Adani M, Almodovar P, Berton E, Bessagnet B, Bohlin-Nizzetto P, Boruvkova J, Breivik K, Briganti G, Cappelletti A, Cuvelier K, Derwent R, D'Isidoro M, Fagerli H, Funk C, Garcia Vivanco M, Haeuber R, Hueglin C, Jenkins S, Kerr J, de Leeuw F, Lynch J, Manders A, Mircea M, Pay MT, Pritula D, Querol X, Raffort V, Reiss I, Roustan Y, Sauvage S, Scavo K, Simpson D, Smith RI, Tang YS, Theobald M, Tørseth K, Tsyro S, van Pul A, Vidic S, Wallasch M, Wind P (2016) EMEP Co-operative programme for monitoring and evaluation of the long-range transmission of air pollutants in Europe. Air pollution trends in the EMEP region between 1990 and 2012. Joint Report of EMEP Task Force on Measurements and Modelling (TFMM), Chemical Co-ordinating Centre (CCC), Meteorological Synthesizing Centre-East (MSC-E), Meteorological Synthesizing Centre-West (MSC-W). EMEP/CCC-Report 1/2016. https://www.unece.org/fileadmin/DAM/env/ documents/2016/AIR/Publications/Air_pollution_trends_in_the_EMEP_ region.pdf. Accessed 31 Jan 2019

7. Engardt M, Simpson D, Schwikowski M, Granat L (2017) Deposition of sulphur and nitrogen in Europe 1900-2050. Model calculations and 
comparison to historical observations. Tellus B Chem Phys Meteorol 69:1-20

8. Frahm JP (1998) Moose als Bioindikatoren. Quelle \& Meyer GmbH \& Co, Wiesbaden

9. Fuchs $\mathrm{S}$, Scherer U, Wander R, Behrendt H, Venohr M, Opitz D, Hillenbrand T, Marscheider-Weidemann F, Goetz T (2010) Berechnung von Stoffeinträgen in die Fließgewässer Deutschlands mit dem Modell MONERIS. Nährstoffe, Schwermetalle und Polyzyklische aromatische Kohlenwasserstoffe. Texte - Umweltbundesamt, Dessau-Rosslau (Deutschland), $45 / 2010,243 \mathrm{~S}$

10. Goovaerts P (1999) Geostatistics in soil science: state-of-the-art and perspectives. Geoderma 89(1-2):1-45

11. Gruber JP (2001) Die Moosflora der Stadt Salzburg und ihr Wandel im Zeitraum von 130 Jahren. Stapfia 79:3-155

12. Harmens H, Norris DA, Steinnes E, Kubin E, Piispanen J, Alber R, Aleksiayenak Y, Blum O, Coşkun M, Dam M, De Temmerman L, Fernández JA, Frolova M, Frontasyeva M, González-Miqueo L, Grodzińska K, Jeran Z, Korzekwa S, Krmar M, Kvietkus K, Leblond S, Liiv S, Magnússon SH, Maňkovská B, Pesch R, Rühling Å, Santamaria JM, Schröder W, Špirić Z, Suchara I, Thöni L, Urumov V, Yurukova L, Zechmeister HG (2010) Mosses as biomonitors of atmospheric heavy metal deposition: spatial and temporal trends in Europe. Environ Pollut 158:3144-3156

13. Harmens H, Mills G, Hayes F, Sharps K, Frontasyeva M, the participants of the ICP Vegetation (2015) Air pollution and vegetation, annual report 2014/2015. ICP Vegetation Programme Coordination Centre, CEH Bangor, UK

14. Herpin U, Lieth H, Markert B (1995) Monitoring der Schwermetallbelastung in der Bundesrepublik Deutschland mit Hilfe von Moosanalysen. UBA-Texte 31/95

15. Isaaks EH, Srivatava RM (1989) An introduction to applied geostatsitics. Oxford University Press, New York

16. ICP Vegetation (2014) Monitoring of atmospheric deposition of heavy metals, nitrogen and POPs in Europe using bryophytes. Monitoring manual 2015 survey. United Nations Economic Commission for Europe Convention on Long-Range Transboundary Air Pollution. ICP Vegetation Moss Survey Coordination Centre, Dubna, Russian Federation, and Programme Coordination Centre. Bangor, Wales, UK

17. ISO (2005) DIN EN ISO 16772:2005-06, Bodenbeschaffenheit - Bestimmung von Quecksilber in Königswasser-Extrakten von Boden durch Kaltdampf-Atomabsorptionsspektrometrie oder Kaltdampf-Atomfluoreszenzspektrometrie (ISO 16772:2004), Ausgabe: 2005-06

18. ISO (2017) DIN EN ISO 17294-2:2017-01, Wasserbeschaffenheit - Anwendung der induktiv gekoppelten Plasma-Massenspektrometrie (ICP-MS) - Teil 2: Bestimmung von ausgewählten Elementen einschließlich Uran-Isotope (ISO 17294-2:2016); Deutsche Fassung EN ISO 17294-2:2016, Ausgabe: 2017-01

19. ISO/IEC (2005) DIN EN ISO/IEC 17025:2005-08, Allgemeine Anforderungen an die Kompetenz von Prüf- und Kalibrierlaboratorien (ISO/IEC 17025), Ausgabe: 2005-08

20. Jenssen M, Hofmann G, Nickel S, Pesch R, Riediger J, Schröder W (2013) Bewertungskonzept für die Gefährdung der Ökosystemintegrität durch die Wirkungen des Klimawandels, Kombination mit Stoffeinträgen unter Beachtung von Ökosystemfunktionen und -dienstleistungen. Umweltforschungsplan des Bundesministeriums für Umwelt, Naturschutz und Reaktorsicherheit. Forschungsvorhaben 371083 214, UBA-FB 001834. Dessau: Umweltbundesamt, UBA-Texte 87/2013. p 381

21. Jenssen M, Schröder W, Nickel S (2015) Typisierung von Wald- und Forstökosystemen als Grundlage zur Einstufung ihrer Integrität. Integrität von Wald- und Forstökosystemen unter dem Einfluss von Klimawandel und atmosphärischen Stickstoffeinträgen - Teil I. Naturschutz und Landschaftsplanung 47:391-399

22. Johnston K, Ver Hoef JM, Krivouchko K, Lucas N (2001) Using ArcGIS geostatistical analyst. Environmental Systems Research Institute, Redlands

23. KratzW, Schröder W (2010) Wider die Vernunft - zum Ende eines Programms effektiver Umweltdatenerhebung in Bund-Länder-Kooperation. Umweltwiss Schadst Forsch 22:80-83

24. Krige DG (1951) A statistical approach to some basic mine valuation problems on the Witwatersrand. J Chem Metallurg Mining Soc S Afr 6:119-139

25. Matheron G (1965) Les variables régionalisées et leur estimation. Masson, Paris
26. Meyer M (2017) Standortspezifisch differenzierte Erfassung atmosphärischer Stickstoff- und Schwermetalleinträge mittels Moosen unter Berücksichtigung des Traufeffektes und ergänzende Untersuchungen zur Beziehung von Stickstoffeinträgen und Begleitvegetation. Diss. Univ. Vechta. http://voado.uni-vechta.de/handle/21.11106/75. Accessed 31 Jan 2019

27. Moran PAP (1950) Notes on continuous stochastic phenomena. Biometrika 37(1):17-23

28. Mohr K (1999) Passive Monitoring von Stickstoffeinträgen in Kiefernforsten mit dem Rotstengelmoos (Pleurozium schreberi (Brid.) Mitt.). Umweltwiss Schadst Forsch 11:267-274

29. Mohr K (2007) Biomonitoring von Stickstoffimmissionen. Möglichkeiten und Grenzen von Bioindikationsverfahren. Umweltwissen-schaften und Schadstoff-Forschung 19:255-264

30. NaSE (2017) Nationale Trendtabellen für die deutsche Berichterstattung atmosphärischer Emissionen (Schwermetalle) 1990-2015, Stand Januar 2017, Umweltbundesamt, Dessau Roßlau. https://www.umweltbund esamt.de/sites/default/files/medien/361/dokumente/2018_02_14_em_ entwicklung_in_d_trendtabelle_hm_v1.0.xlsx. Accessed 31 Jan 2019

31. NaNE (2017) Nationale Trendtabellen für die deutsche Berichterstattung atmosphärischer Emissionen (Stickstoff) 1990-2015, Stand Januar 2017, Umweltbundesamt, Dessau Roßlau. https://www.umweltbundesamt.de/ sites/default/files/medien/361/dokumente/2018_02_14_em_entwicklun g_in_d_trendtabelle_luft_v1.0.xlsx. Accessed 31 Jan 2019

32. Nickel S, Schröder W (2017) Integrative evaluation of data derived from biomonitoring and models indicating atmospheric deposition of heavy metals. Environ Sci Pollut Res 24:11919-11939

33. Nickel S, Schröder W (2017) Bestimmung von Schwermetalleinträgen in Waldgebiete mit Modellierung und Moosmonitoring. Schweizer Zeitschrift für Forstwesen 168(2):92-99

34. Nickel S, Schröder W (2017) Reorganisation of a long-term monitoring network using moss as biomonitor for atmospheric deposition in Germany. Ecol Ind 76:194-206

35. Nickel S, Schröder W (2017) Metalleinträge in terrestrische Ökosysteme: analyse von Daten aus Modellierung und Biomonitoring. Schweizerische Zeitschrift für Forstwesen 168(4):1-9

36. Nickel S, Schröder W, Fries C (2017) Synoptische Auswertung modellierter atmosphärischer Einträge von Schwermetallen und deren Indikation durch Biomonitore in Wäldern.Gefahrstoffe - Reinhaltung der Luft (Springer, VDI) 3/2017:75-90

37. Nickel S, Schröder W, Jenssen M (2015) Veränderungen deutscher Wälder durch Klimawandel und Stickstoffdeposition. Schweizerische Zeitschrift für Forstwesen 166(5):325-334

38. Nickel S, Schröder W (2018) Schwermetall- und Stickstoffkonzentrationen in Moosen deutscher Waldgebiete zwischen 1990 und 2015 - Ein BundLänder-Vergleich. Gefahrstoffe - Reinhaltung der Luft 78(3):95-108

39. Nultsch W (2012) Allgemeine Botanik, 12th edn. Thieme, Stuttgart

40. Olea RA (1999) Geostatistics for engineers and earth scientists. Kluwer Academic Publishers, Boston

41. Pesch R, Schröder W, Genssler L, Goeritz A, Holy M, Kleppin L, Matter Y (2007) Moos-Monitoring 2005/2006: Schwermetalle IV und Gesamtstickstoff. Berlin (Umweltforschungsplan des Bundesministers für Umwelt, Naturschutz und Reaktorsicherheit. FuE-Vorhaben 20564200 , Abschlussbericht, im Auftrag des Umweltbundesamtes), 90 S., 11 Tab., 2 Abb. (Texteil), 51 S. +41 Karten, 34 Tabellen, 46 Diagramme (Anhang)

42. Pesch R, Schröder W (2006a) Mosses as bioindicators for metal accumulation: statistical aggregation of measurement data to exposure indices. Ecol Ind 6:137-152

43. Pesch R, Schröder W (2006b) Integrative exposure assessment through classification and regression trees on bioaccumulation of metals, related sampling site characteristics and ecoregions. Ecol Inf 1(1):55-65

44. Pesch R, Schröder W (2006c) Assessment of metal accumulation in mosses by combining metadata, statistics and GIS. Nova Hed-wigia 82(3-4):447-466

45. Pesch R, Schröder W, Dieffenbach-Fries H, Genßler L (2007) Optimierung des Moosmonitoring-Messnetzes in Deutschland. Umweltwiss Schadst Forsch 20:49-61

46. Pesch R, Schröder W, Dieffenbach-Fries H, Genßler L, Kleppin L (2008) Improving the design of environmental monitoring networks. Case study on the heavy metals in mosses survey in Germany. Ecol Inform 3:111-121 
47. Reimann C, Filzmoser P (2000) Normal and lognormal data distribution in geochemistry: death of a myth. Consequences for the statistical treatment of geochemical and environmental data. Environ Geol 39(9):1001-1014

48. Rühling A, Rasmussen L, Mäkinen A, Pilegaard K, Steinnes E, Nihlgard B (1989) Survey of the of the heavy-metal deposition in Europe using bryophytes as bioindicators: proposal for an international programme. Steering Body of Environmental Monitoring in the Nordic Countries

49. Sachs L, Hedderich J (2009) Angewandte Statistik. Methodensammlung mit R. Springer, Berlin

50. Schaap M, Roemer M, Sauter F, Boersen G, Timmermans R, Builjes PJH, Vermeulen AT (2005) LOTOS-EUROS: Documentation, TNO report B\&O-A R 2005/297

51. Schaap M, Timmermans RMA, Roemer M, Boersen GAC, Builtjes PJH, Sauter FJ, Velders GJM, Beck JP (2008) The LOTOS-EUROS model: description, validation and latest developments. Int J Environ Pollut 32(2):270-290

52. Schaap M, Hendriks C, Jonkers S, Builtjes P (2017) Impacts of heavy metal emission on air quality and ecosystems across germany. Sources, transport, deposition and potential Hazards. part 1: assessment of the atmospheric heavy metal deposition to terrestrial ecosystems in Germany. Final report FKZ3713 63 253. Dessau-Roßlau, Germany. https://www.umwel tbundesamt.de/sites/default/files/medien/1410/publikationen/2018-1213_texte_106-2018_schwermetallemissionen_en.pdf. Accessed 21 May 2019

53. Schröder W, Anhelm P, Bau H, Broecker F, Matter Y, Mitze R, Mohr K, Peiter A, Peronne T, Pesch R, Roostai AH, Roostai Z, Schmidt G, Siewers U (2002) Untersuchung von Schadstoffeinträgen anhand von Bioindikatoren. Aus- und Bewertung der Ergebnisse aus dem Moosmonitoring 1990, 1995 und 2000. Umweltforschungsplan des Bundesministers für Umwelt, Naturschutz und Reaktorsicherheit. FuE-Vorhaben 20064 218, Abschlussbericht Band 1, im Auftrag des Umweltbundesamtes, Berlin. 221 S., 29 Tab., $94 \mathrm{Abb}$

54. Schröder W, Hornsmann I, Pesch R, Schmidt G, Fränzle S, Wünschmann S, Heidenreich H, Markert B (2006) Stickstoff- und Metallakkumulation in Moosen zweier Regionen Mitteleuropas als Spiegel ihrer Landnutzung? Umweltwissenschaften und Schadstoff-Forschung (Online First 24.11.2006), S. 1-12

55. Schröder W, Nickel S, Jenssen M, Riediger J (2015) Methodology to assess and map the potential development of forest ecosystems exposed to climate change and atmospheric nitrogen deposition: a pilot study in Germany. Sci Total Environ 521-522:108-122

56. Schröder W, Pesch R (2004a) The 1990, 1995 and 2000 moss monitoring data in Germany and other European countries. Trends and statistical aggregation of metal accumulation indicators. Gate to Environmental and Health Sciences, June 2004, pp. 1-25

57. Schröder W, Pesch R (2004b) Metal accumulation in mosses. Spatial analysis and indicator building by means of GIS, geostatistics and cluster techniques. Environ Monit Assess 98(1-3):131-156

58. Schröder W, Pesch R (2004c) Spatial and temporal trends of metal accumulation in mosses. J Atmos Chem 49:23-38

59. Schröder W, Pesch R (2005b) Geographische Umweltmessnetzanalyse und -planung. Geog Helv 60(2):77-86

60. Schröder W, Pesch R (2007) Synthesizing bioaccumulation data from the German metals in mosses surveys and relating them to ecoregions. Sci Total Environ 374:311-327
61. Schröder W, Nickel S, Schönrock S, Meyer M, Wosniok W, Harmens H, Frontasyeva MV, Alber R, Aleksiayenak J, Barandovski L, Danielsson H, de Temmermann L, Fernández Escribano A, Godzik B, Jeran Z, Pihl Karlsson G, Lazo P, Leblond S, Lindroos AJ, Liiv S, Magnússon SH, Mankovska B, Martínez-Abaigar J, Piispanen J, Poikolainen J, Popescu IV, Qarri F, Santamaria JM, Skudnik M, Špirić Z, Stafilov T, Steinnes E, Stihi C, Thöni L, Uggerud HT, Zechmeister HG (2016) Spatially valid data of atmospheric deposition of heavy metals and nitrogen derived by moss surveys for pollution risk assessments of ecosystems. Environ Sci Pollut Res 23:10457-10476

62. Schröder W, Nickel S, Völksen B, Dreyer A (2018) Nutzung von Bioindikationsmethoden zur Bestimmung und Regionalisierung von Schadstoffeinträgen für eine Abschätzung des atmosphärischen Beitrags zu aktuellen Belastungen von Ökosystemen. F\&E-Vorhaben 371563212 0, Abschlussbericht, im Auftrag des Umweltbundesamtes, Dessau. Text 188 S. +10 Anhänge (zusammen 376 S.)

63. Schröder W, Riediger J, Nickel S, Jenssen M (2016) Projektion zukünftiger Ökosystemzustände unter dem Einfluss von Klimawandel und atmosphärischen Stickstoffeinträgen. Integrität von Wald- und Forstökosystemen unter dem Einfluss von Klimawandel und atmosphärischen Stickstoffeinträgen - Teil II. Naturschutz und Landschaftsplanung 48(1):22-28

64. Shapiro SS, Wilk MB (1965) An analysis of variance test for normality (complete samples). Biometrika 52:591-611

65. Siewers U, Herpin U (1998) Schwermetalleinträge in Deutschland. Moos-Monitoring 1995. Geologisches Jahrbuch, Sonderhefte, Heft SD 2, Bornträger, Stuttgart

66. Steinnes E, Rühling A, Lippo H, Mäkinen A (1997) A reference materials for large-scale metal deposition surveys. Accred Qual Assur 2:243-249

67. Travnikov O, Ilyin I (2005) Regional model MSCE-HM of heavy metal transboundary air pollution in Europe. EMEP/MSC-E Technical Report 6/2005. p 59

68. Travnikov O, llyin I, Rozovskaya O, Varygina M, Aas W (2015) Heavy metals: analysis of long-term trends, country-specific research and progress in mercury regional and global modelling Meteorological Synthesizing Centre, East, Moscow (MSC-E, Russia) and Norwegian Institute for Air Research, Kjeller (CCC, Norway). MSC-E \& CCC-Status Report 2/2015. p 70

69. VDLUFA (Verband Deutscher Landwirtschaftlicher Untersuchungs- und Forschungsanstalten) (1995) Methodenbuch, Band II.1. Die Untersuchung von Düngemitteln, 3.5.2.7 Bestimmung von Gesamt-Stickstoff, Verbrennungsmethode, 4. Aufl., Gesamtwerk einschl. 1.-6. Ergänzung (einschl. Ringordner), VDLUFA-Verlag, Darmstadt

70. Warf B (ed) (2010) Encyclopedia of geography. Sage Publications, Thousand Oaks

71. Webster R, Oliver MA (2001) Geostatistics for environmental scientists. Wiley, Chichester

72. WGE (2004) Review and assessment of air pollution effects and their recorded trends. Working group on effects, convention on long-range transboundary air pollution. National Environment Council UK

\section{Publisher's Note}

Springer Nature remains neutral with regard to jurisdictional claims in published maps and institutional affiliations.

\section{Submit your manuscript to a SpringerOpen ${ }^{\circ}$ journal and benefit from:}

- Convenient online submission

- Rigorous peer review

- Open access: articles freely available online

- High visibility within the field

- Retaining the copyright to your article

Submit your next manuscript at springeropen.com 